\title{
The Training of Chinese Managers: A Critical Analysis of Using Overseas Training for Management Development
}

\author{
Xiao Sun \& Catharine Ross \\ University of Worcester Business School, UK
}

\begin{abstract}
Chinese policy makers are aware that developing China's managers is crucial to creating competitive advantage in the post-WTO period. Consequently large numbers of Chinese managers have been sent abroad, particularly to the Western and developed countries, on management training courses in order to bring new ideas and approaches to their organisations. This paper addresses the empirical deficiencies of research on Chinese managers' development activities in the Western countries and questions whether these training programmes have successfully achieved their objectives. The empirical study is adopted to invite the opinions of different stakeholder groups involved in the training process (526 participants). Specific characteristics of China's overseas management training are discussed and problem areas are also explored.
\end{abstract}

Key Words: Overseas training, management development, China

\section{Introduction}

Since opening-up to the world in the late 1970s China has effected a transition from a command economy to a socialist market economy (Warner, 1993; Glover and Siu, 2000; Warner, 2004; Child and Rodrigues, 2005). Economic reform has led to changes in organisational structure and management practices, which in turn impact on organisational culture and re-shape people's norms and values (Child, 1994; Goodall et al., 2004). Further in 1987 the reform of Chinese civil service and cadre system launched by Deng and his colleagues sought to improve performance through training and education (Chow, 1991; Cooke, 2003). Moreover China's new accession to the WTO (World Trade Organisation) and globalisation is exerting great pressure on Chinese policymakers to make fundamental changes and accelerate the transition to a market economy. Many commentators focus on analysing the reasons for change, and types of changes, as well as the management transition in organisations (McCalman and Paton, 1992; Thornhill et al., 2000). It is also argued (Griffiths and Williams, 1999; Barry, 1999) that the important issue about managing change is for policy makers to have a clear vision of their organisations and link human resource development to the business strategies. 
There is a growing consensus that the quality of an organisation's human resource is a critical factor in the success of that organisation (Pilbeam and Corbridge, 2002; Mendenhall et al., 2003; Warner, 2004). Management development has therefore become a strategic goal for organisations since the 1990s (Beardwell and Holden, 2001). Many authors argue (Borgonjon and Vanhonacker, 1994; Mintzberg and Gosling, 2002; Frese et al., 2003; Cooke, 2005; Longenecker and Laurence, 2005) that management training and education are important means of improving managerial personnel in an organisation. Deng Xiao-ping, the architect of China’s economic reform and open-door policy, recognised that to change people's mindset was of primary importance to foster the economic change in China. He (Deng, 1978a; Deng, 1978b; Deng, 1982) pointed out that China's modernisation required the assimilation and learning of advanced foreign knowledge, managerial experience and all the fruits of human civilization. The “2002-2005 National Talent Team Construction Plan” issued by the Administration Offices of the Chinese Communist Party and State Council (Xinhuanet 2002) raises the awareness of human resources development and talent competition in China. One of the strategies is:

“To build up a management team who master the knowledge of international economy and law... to choose them to take training courses both in China and abroad, to send them to learn, to practice in big companies abroad and to increase their managerial competence which complies with international business norms and regulations.”

The managerial competencies for a global world require modern management knowledge and skills, which can be achieved by education and training. In order to sustain growth in the fierce competition of globalisation and the new environment of China's post WTO, the Chinese government has placed more emphasis on the development of high quality talent. Therefore investment in management training and education has become an important part of China's economic development ( Warner, 1993; Borgonjon and Vanhonacker, 1994;Warner, 2004; Chu Ng and Siu, 2004; Cooke, 2005). Starting in the late 1970s China has been sending professionals and managers to study or to take training courses in developed countries and areas. As China's economy has developed it has become a prevailing human resource activity for policy makers to initiate overseas management training programmes for developing managerial competences and skills (People's Daily Online, 2001).

The purpose of this paper is to examine critically whether China's overseas 
management training and development programmes have achieved their objectives. More specifically, it focuses on those programmes initiated by the China Association for International Exchange of Personnel (CAIEP), which is one of the organisations authorised in China to organise and implement overseas management training and development.

The organisation of this paper is as follows. The following section conducts a literature review and identifies the deficiencies of previous studies in relation to management training and development. The section after briefly describes the methodological approach of this research. The third section presents empirical results, followed by discussions of findings and elaboration of their implications for management development. The last section concludes the paper.

\section{Literature Review and Research Deficiencies}

\section{Concept of management development}

The concept of management development has been interpreted in various ways. Mullins (2002:851) argues that "there is no single, agreed definition of management development”. Mumford (1989:5) is critical to the definition of a training services agency that management development is "an attempt to improve managerial effectiveness through a planned and deliberate learning process”. He (Mumford, 1997) argues that to refer to management development as a 'formal, planned and deliberate process' is narrow and flawed. Mumford (1997) suggests that the concept of management development should include formal management development activity and informal learning and thus describes management development as 'an attempt to improve managerial effectiveness through a learning process' (1989:5).

Thomson and his colleagues (2001:10) agree with Mumford's arguments (1997) by suggesting management development is a "multi-faceted process", which includes not only "formal learning of knowledge and skills" through training and education, but also “informal and experiential modes of human capital formation”. Mabey and Thomson (2000:276) also suggest including informal development activities in the entire organisational development protocol, which aims to improve their managers' knowledge and skills. They argue that a formal training programme is not the only solution for management development, as much learning is gained from experiences. Similarly, Mintzburg (2004) points out that good managers are not created from the 
classroom. Mumford (1997: 38) therefore suggests the marriage of formal and informal learning experiences in the development process. Branine (2005) produces a good example of this in his work with Chinese management development programmes. He argues that learning can take place in the form of the daily interaction and managerial reality of Chinese managers and their Western partners rather than in the classroom.

However a review of literature shows that there is a paucity of empirical studies demonstrating the practical linkage of formal and informal management development. In particular publications on management training for developing Chinese managers in Western countries are rare. Moreover some research (Mabey and Thomson, 2000; Thomoson, et al., 2001) has revealed that informal management development is less associated with an organisational management development system than the formal development activities.

\section{Definition of Management Training and Management Development}

It is apparent that the definitions of 'development' and 'training' are often blurred. For example, Hamblin (1974) uses 'training' to include 'development', which can be regarded as training activity for a future job, whereas Mabey (2002) uses the term 'training' and 'development' interchangeably to cover formal training and informal development activities that managers engage in to improve their knowledge, abilities and skills.

A traditional definition of training is that "The systematic development of the knowledge/skill/attitudes required by a person in order to perform effectively a given task or job” (Development of Employment, 1971:29). Hamblin (1974:6) simply describes training as "any activity which deliberately attempts to improve a person's skill in a job”. Some writers stress the individual's learning related to the present job and immediate changes in job performance (Nadler, 1984; Rothwell and Kazanas, 1994). Cambell, et al. (1970) defines training as a planned learning experience designed to bring about permanent change in an individual's knowledge, attitudes, or skills.

Later studies develop the debate on 'training'. For example, Mayo (1998) argues that the term training has developed from the traditional meaning of programmes or activities to include various ways or methods of learning both for the present job and 
future demands. Bramley’s view supports Mayo’s argument. Bramley (1996:xvii) suggests that "training aims at improving performance at present and future and therefore enhances the effectiveness of an organisation where the trainees (individual and group) work”. This might account for the overlapping of the terms of training and development.

There are some attempts to distinguish between training and development. For example, Mullins (Mullins, 2002:844) suggests that training is normally the basic means in the development process and training usually emphasises the improvement of managers' performance for their current job. Development has more of an emphasis on their ability to manage change and their qualification for future positions. Rothwell and Kazanas (1994:397) agree with Mullins' argument and point out that training focuses on individual learning related to job requirements while development "contributes to organisational learning by cultivating the collective skills of individuals in group settings".

Bernhard and Ingols (1988:41-42) argue that development "broadens people and gives them new perspectives”, which emphasises developing organisational top managers and leadership. Training is, however, "a short-term activity that helps people to do their job better, to become skilled specialists". In other words "training is improvement for today and development is an investment for tomorrow”.

Easterby-Smith (1994:10-11) contests the traditional definitions between 'training' and 'development': 'training' aims at improving managers' current performance, while 'development' aims at improving managers' future performance. He argues against basing the definitions on the obvious goals of programmes whilst the concept of goal and objectives of training and development is problematic in the first instance. Easterby-Smith (1994:12) defines training as a procedure involving managers attending a course or a workshop. His view agrees with the suggestion by Ashton and Esterby-Smith (1978) that training is regarded as a sub-system of management development.

\section{Training Provisions in the Process of Management Development}

There is an increasing consensus that any management development activities should link to organisational business strategies as well as managers' real work practices (Bolt et al., 1983; Holden, 1991; Badger and Sadler-Smith, 1997; Sels, 2002). Mumford 
(1997) argues that the process and content of any training initiatives leads to ineffective learning if they are divorced from management reality. It is also stressed that the key to achieving effective training is to provide what the managers want to learn when they need to learn (Bolt et al., 1983; LaHote et al., 1999). Professional developers are criticised for tending to adopt their preferred approaches, i.e., tutor and learner stereotypes or trainer-centred methods to provide management training and professional education rather than focusing on the real interests and levels of understanding of learners (Mumford, 1997; Branine, 2005).

Therefore the training providers should have a clear mind of what the managers' needs are and what their organisations' objectives for the particular management development intervention are. Bernhard and Ingols (1988) argue that the frequent problem for professional developers is running programmes which are not relevant to strategic organisational goals. On the other hand, the training must be delivered in a format that best suits the individuals' learning style and must be transferable from conceptual understanding to real work application (LaHote et al., 1999). Likewise, Alon and Lu (2004) raise the pedagogical issue of management education in China delivered through Western-based approaches. There is therefore a need to study the method of delivery of management development programmes across cultures.

However a review of previous research on management training and development has shown the paucity of studies on the effectiveness of Chinese managers' development activities in Western countries. As elaborated earlier China's overseas management training is a method of developing managers to embrace changes and to achieve improved performance in different organisational sectors and at different levels. Therefore, in the context of management development China's overseas management training intervention refers to a systematic development of managers' knowledge, skills, attitudes and other abilities in order to improve the performance of managers' and their organisations' through a planned and structured learning process with emphasis on business reality.

Unlike local management training China's overseas management training is underpinned by a broader context involving two cultures. In addition the perceptions on the effectiveness of training vary among the stakeholders from different cultures. Some studies have demonstrated problems in the cross-cultural learning of international 
students and expatriate managers as well as in the transfer of knowledge from Western to non-Western settings (Newell, 1999; Berrell et al., 2001; Batonda and Perry, 2003; Iles et al., 2004; Selvarajah, 2006;). This paper aims to make empirical contributions to the theory of management training and development by (a) exploring the characteristics of China's overseas management training and development process, (b) evaluating whether these programmes have achieved their objectives from the perspectives of the major stakeholders, (c) identifying the key factors which influence Chinese managers' learning in host countries and, (d) identifying the impact of overseas management training.

\section{Methodology}

This research targets defined populations in the intervention of China's overseas management training and development. They are categorised into five groups as below:

(1) Trainees who were taking training in the UK in 2004

(2) Ex-trainees who took training in Western countries during 2000 2003 and returned back to their work.

(3) Training managers and officials who were in charge of and/or organised overseas management training.

(4) Lecturers and training managers in the UK training institutions/organisations who delivered management training courses for Chinese managers.

(5) Ex-trainees' supervisors who worked as line managers of ex-trainees

This research adopted a blend of probability sampling of a defined larger population for the questionnaire survey, and stratified purposive sampling for semi-structured interviews and focus group interviews (Tashakkori and Teddlie, 1998; Kemper et al., 2003). The empirical data was collected from focus groups, questionnaire survey and semi-structured interviews. As shown in Table 1 17\% of respondents participated in focus groups, $16 \%$ in interviews and $66 \%$ in questionnaire survey. This research design was based on the principle of using different methods in data collection to achieve different purposes (Jick, 1979; Silverman, 2000; Johnson and Turner, 2003). In this case the questionnaire survey was to collect larger amount of quantitative data, whilst the focus group and semi-structured interviews aimed at gathering smaller numbers of qualitative information for piloting and in-depth exploration in a pro-active process. 
Table 1 Data Collection

\begin{tabular}{|c|c|c|c|c|c|c|c|c|}
\hline \multirow{2}{*}{ Participant } & \multicolumn{2}{|c|}{$\begin{array}{c}\text { Focus } \\
\text { groups }\end{array}$} & \multicolumn{2}{c|}{$\begin{array}{c}\text { Questionnaires } \\
\text { Survey }\end{array}$} & \multicolumn{2}{c|}{$\begin{array}{c}\text { Semi-structured } \\
\text { interviews }\end{array}$} & \multicolumn{2}{c|}{$\begin{array}{c}\text { Total } \\
\text { (\%) }\end{array}$} \\
\hline Trainees & No & $\%$ & No & $\%$ & No & $\%$ & No & $\%$ \\
\cline { 2 - 10 } & 20 & 14 & 95 & 68 & 24 & 18 & 139 & 100 \\
\hline Ex-trainees & 48 & 24 & 120 & 61 & 30 & 15 & 198 & 100 \\
\hline $\begin{array}{c}\text { Training staff and } \\
\text { officials in China }\end{array}$ & 10 & 16 & 45 & 68 & 11 & 16 & 66 & 100 \\
\hline $\begin{array}{c}\text { Training managers } \\
\text { and lecturers in } \\
\text { UK }\end{array}$ & 8 & 12 & 48 & 71 & 12 & 17 & 68 & 100 \\
\hline $\begin{array}{c}\text { Ex-trainees' } \\
\text { supervisor }\end{array}$ & 5 & 10 & 40 & 72 & 10 & 18 & 55 & 100 \\
\hline Total (No) & 91 & 17 & 348 & 66 & 87 & 16 & 526 & 100 \\
\hline
\end{tabular}

The research process involved seven stages which integrated with the two phases of data collection. They were: (a) instrument development, (b) match the research questions with responses, (c) concurrent preliminary data analysis, (d) data comparison, (e) data integration, (f) data verification, and (g) data interpretation.

Efforts were made to maximise the measurement reliability in the empirical studies and minimise the introduction of bias. The validity of findings was attained by three methods: (a) through a systematic process by employing an interaction model of research design, (b) through triangulation of data sources (perspectives of stakeholder groups), and (c) through triangulation of multi-methods (quantitative and qualitative). Moreover the strategy of employing both probability sampling and purposive sampling enables the generalisability of the findings to a new setting and larger population with similar characteristics (Kemper et al., 2003). The bilingual and cross-cultural skills of the researcher (also interviewer) contributed to the reliability and successfulness of the empirical studies which involved two different cultural settings: China and Anglo-Saxon.

\section{Empirical Findings}

\section{Characteristics of China's overseas training intervention}

The attributes of the survey respondents from the major stakeholders are analysed by their age, organisational sector, job role, and educational background. Three phases of overseas training (refer to Table 2) have been initiated by the Chinese government since 
China implemented economic reform. This study focuses on the period of 2000 2004 in the third phase of managerial training and development starting from 1996. Hundreds and thousands of Chinese managers are sent by their provincial government and organisation to advanced and developed countries, particularly Western countries, to take less than one month to a year and plus training courses or degree studies. These managers are mostly in the age group 30-45 and are educated to degree level. The majority of them are middle and senior managers or professionals in government organisations, public services, and enterprises. The analysis also shows that in the UK most of the training is delivered by educational institutions.

Table 2 Phases of China's Overseas Management Training

\begin{tabular}{|l|l|l|}
\hline \multicolumn{1}{|c|}{ Time Span } & \multicolumn{1}{|c|}{ Subject } & \multicolumn{1}{c|}{ Definitions } \\
\hline Late 70s late 80s & Technical training & $\begin{array}{l}\text { Chinese professionals are sent to developed } \\
\text { countries and areas to learn advanced/ } \\
\text { modern technology in science, industry, and } \\
\text { agriculture. }\end{array}$ \\
\hline Early 90s mid 90s & $\begin{array}{l}\text { Mixture of } \\
\text { technical training } \\
\text { and management } \\
\text { training }\end{array}$ & $\begin{array}{l}\text { Technical and managerial persons are sent to } \\
\text { developed countries and areas to learn } \\
\text { advanced/ modern technology and } \\
\text { management. }\end{array}$ \\
\hline 1996 present & $\begin{array}{l}\text { Managerial skills } \\
\text { training, } \\
\text { leadership } \\
\text { development, and } \\
\text { high-tech } \\
\text { intellectuals } \\
\text { training }\end{array}$ & $\begin{array}{l}\text { Senior managers/executives from government } \\
\text { departments/ organisations and enterprises } \\
\text { (usually state-owned and state share-holding } \\
\text { companies) are sent to developed countries } \\
\text { and areas, particularly the Western countries } \\
\text { to learn Western/advanced management } \\
\text { knowledge, skills, practices and experiences. }\end{array}$ \\
\hline
\end{tabular}

China's overseas management training is normally taken in groups rather than on an individual basis and the trend is towards more medium-term training for its cost-effective value. The most popular subjects of training are public administration, business management, human resource management, economics, and finance. The training experienced by the respondents includes not only classroom teaching but also other forms like seminars, company visits and work experience in the host countries. The findings reveal that training departments/organisers are perceived by the stakeholders to have the biggest influence on training development, on issues such as training objectives, subject matters, trainees' selection, while training institutions are perceived to have less influence. On the other hand UK training institutions are found to 
have more influence on course design and delivery than other groups. The least influential groups are perceived to be trainees, and trainees' organisations. Training objectives are largely based on local government development strategy and job requirement according to analysis of the responses to the questionnaire survey.

Different perceptions and understandings about the above subjects are found between stakeholder groups. For example, different stakeholders respond quite differently about who decides on training objectives, particularly to the influence of 'training departments', and 'training organisers'. The respondents from UK training institutions have more awareness than other groups that trainees and ex-trainees should have more say in objective making. On the other hand ex-trainees' supervisors observe less involvement of their organisations in trainees' selection than the other groups, while many of the respondents from UK training institutions do not know who is involved in making training objectives, or trainees' selection and what the criteria are.

\section{Evaluation of the Effectiveness of Training Delivery}

The results from both quantitative and qualitative analysis show different viewpoints and arguments between groups with regard to evaluation of effectiveness of training delivery. This section explains these issues.

Firstly, there are three levels of objectives as follows.

Designed Objectives - the objectives stated in the protocol or agreement between overseas training institution and training organiser in China.

Trainees' Organisational Objectives - the objectives of the organisation in which the trainees work for.

Individual Objectives - the objectives of Chinese managers who participate training, which in turn determined by individual needs and expectations.

Secondly, the statistical analysis shows that the respondents from training institutions are least clear about the details of the objectives but are most positive that the training programmes are consistent with the objectives among the groups. Trainees’ organisation objectives are perceived to be least met followed by individual objectives.

Thirdly, the assessment of training delivery in terms of instruction, approach, and services of the training institution reveals that the training institution group is also most satisfied with the quality of training programmes; whereas Chinese managers are critical of the quality of training delivery. For example, one of trainees was critical about the 
training provider and said, “...The host institution did not know our culture and customs, so our needs were sometimes regarded as 'unreasonable requirements', or to be considered too demanding...They were very slow to respond to our urgent requests.” On the other hand evidence from interviews suggests that either somewhere in the process an obstacle exists preventing training institutions from understanding what the real needs are, or the training institutions have different criteria for evaluation. For instance, one of the lecturers complained: "Very often I am not sure what students have been promised prior to the lecture. There is an issue about knowing what is really required. Sometimes I could not get a clear picture of the requirement and even the dates of teaching well in advance”.

Fourthly, the Chinese stakeholders emphasise managerial activities, business discussions and cultural experience in host country, whilst the participants from UK training institutions focus on classroom teaching. One of the ex-trainees expressed his view: "I think classroom teaching takes too much of our training. The lecturers keep on talking pure theory and that gives little help in solving our managerial problems at work. ...." Some different opinions were heard from the participants of UK training institutions, for instance, one lecturer said: “... I find some trainees have too high and unrealistic expectations.” In addition training manager from UK training institution mentioned that it was more challenging to arrange work practice for trainees than to provide classroom teaching.

\section{Factors Affecting Learning}

The exploration of factors affecting effectiveness of training identifies the key factors and sub factors in management learning by means of statistic analysis (refer to Table 3). There are nine key factors; they are language ability, cultural impact, objectives and needs, programme design, quality of delivery, communication skills, individual characteristics, living conditions, and assessment criteria for learning outcomes. Eight less influential factors are also identified, they are pre-training preparation, practice and company visits, concept, management of training activity, group, context, and academic facilitation and accommodation. 
Table 3 A Glossary of Factors Affecting Learning of Chinese Managers

\begin{tabular}{|c|c|c|}
\hline & Factor & Contents \\
\hline \multirow{9}{*}{ Key factors } & Language & Foreign language barrier, translation. \\
\hline & Culture & $\begin{array}{l}\text { Cultural difference, cross-cultural impact, cultural } \\
\text { visits. }\end{array}$ \\
\hline & Programme design & $\begin{array}{l}\text { Design and organisation of courses in terms of } \\
\text { contents, methods, and schedule. }\end{array}$ \\
\hline & Delivery & $\begin{array}{l}\text { Instruction, approach, quality of training, } \\
\text { commitment of training institution. }\end{array}$ \\
\hline & Objectives/Needs & $\begin{array}{l}\text { Objectives of training, organisational needs, } \\
\text { individual needs. }\end{array}$ \\
\hline & Communication & $\begin{array}{l}\text { Communication skills with local people, students, } \\
\text { lecturers, ability of intercultural communication. }\end{array}$ \\
\hline & Individual & $\begin{array}{l}\text { Background, attitude, learning style, incentive, } \\
\text { experiences. }\end{array}$ \\
\hline & Living & Accommodation, environment. \\
\hline & $\begin{array}{l}\text { Assessment/ } \\
\text { Evaluation }\end{array}$ & $\begin{array}{l}\text { Assessment of learning outcomes, evaluation of } \\
\text { delivery. }\end{array}$ \\
\hline \multirow{8}{*}{ Sub factors } & $\begin{array}{l}\text { Pre-training } \\
\text { Preparation }\end{array}$ & Pre-course induction, cross-cultural training. \\
\hline & $\begin{array}{l}\text { Practice/On-Site } \\
\text { Visits }\end{array}$ & Work replacement, business visits. \\
\hline & Facilitation/Services & Support for trainees' learning, services in living. \\
\hline & Group & $\begin{array}{l}\text { Unity, discipline, differentiation of needs, } \\
\text { leadership. }\end{array}$ \\
\hline & Time/Budget & Availability of time and budget. \\
\hline & Context/Background & $\begin{array}{l}\text { Space, Political system, Social structure, economic } \\
\text { development. }\end{array}$ \\
\hline & Concept & Conception, notion, way of thinking, perception. \\
\hline & Management & $\begin{array}{l}\text { Operation, cooperation, schedule, communication, } \\
\text { commitment. }\end{array}$ \\
\hline
\end{tabular}

The interviews with different stakeholder groups highlights some factors influencing Chinese managers' learning and provides in-depth understanding of these factors.

Firstly, learning in a foreign language is probably the major barrier in the process of learning and teaching for Chinese managers. Secondly the cultural differences between the host country and home country have multiple effects on learning effectiveness. They are (a) the psychological well-being of Chinese managers due to cultural shock, (b) conceptual and perceptual differences about managerial operations between the Chinese managers and lecturers and local professionals, (c) different approaches to the methods of learning and teaching, as well as, (d) the applicability of the designed programmes to China's business environment and management system.

Moreover the designation of Chinese managers' learning in overseas management 
training involves not only theory learning but also various practical activities in the host country such as work experiences, business networking and cultural exchanges with local professionals and communities. Last but not least, studying and living in Western countries Chinese managers encounter varieties of difficulties in everyday life such as accommodation, transport, information access, language barriers, and cross-cultural adaptation.

However the results reveal differences in prioritising these factors by individual stakeholder groups. In addition different awareness of these factors are identified between groups. Firstly, the groups of training institutions and trainees' are found to be less focused on the factors of 'practice/on-site visits', whereas the groups of ex-trainees' and training departments/organisers emphasises 'practice/on-site visits'. Secondly, compared with other groups it appears that the training institution group have less awareness of the factors 'programme design', and 'living', whilst having more recognition of the factors of 'pre-course preparation', 'individual', 'group', 'objective/needs', and 'context/backgrounds'. Thirdly, the training departments/ organisers' group prioritises the factors 'programme design', and 'time/budget', but is less aware of the factor 'culture', and 'objectives/needs' among the stakeholders.

\section{Impact of Overseas Management Training}

It has already been discussed that Chinese policy makers believe that a 'high-level international personnel training and development strategy' provides a solution to the new challenges presented by China's WTO membership and globalisation. The findings reveal that there are indeed multiple positive impacts of overseas management training which can be categorised into four main effects.

(a) Talent benefit refers to developing middle and senior managers both in public services, industrials and commercial business. The results have shown changes in the mindset of Chinese managers. The improvement of ex-trainees' competences are demonstrated at different organisational sectors: (a) ability in decision-making of the leaders in governing party and government organisations, (b) managerial skills of senior managers of enterprises, and (c) innovative capability of professionals. Having been exposed to Western culture and society, Chinese managers have experienced different values, norms, customs and ways of thinking. They have learned to look at things from a global perspective and they are more tolerant of the diversity of cultures. 
(b) Economic benefit implies the process of positive transfer of learning and the impact on the economic development of trainees' organisations, cities and provinces. The benefits are reflected not only in ex-trainees’ organisations but also in regional economy. Some interviewed supervisors considered overseas management training a 'wise, effective and high return on investment' intervention. It promotes innovation in institutional structures and management systems to facilitate local economy and business. It also helps to develop a market economy and foreign-oriented business that stimulates China’s post WTO implementation and globalisation. “....We can also draw lessons from the mistakes Westerns have made”, said one ex-trainees. It is noticed that some managers have contributed to their organisations by using their foreign languages and global vision, which promotes foreign-oriented economic development.

(c) Social benefit includes changes of notion about governmental department functioning, service oriented public administration, and various initiatives of social development projects. The interviews have shown examples of setting up an E-Government website, and establishing an "anti-corruption web”, which increased the transparency of government service and promoted the construction of integrity government. Some other cases are mentioned by the interviewees of the awareness of environment protection, communication of ancient city preservation and education, which promotes healthy growth of China's economy and social development.

(d) Openness benefit implies conceptual changes of Chinese managers and the efforts made by them to bridge China and the West and to promote friendship between their peoples. The promotion of China to the Western countries and vice verse leads to a better understanding of the diversity of the global world as well as to establish smooth communication with the rest of the world. Some interviewees called trainees "friendship ambassadors". "Some trainees used the chance to publicise China in host countries by organising activities such as 'Cultural Festivals', and 'Investment Environment Weeks' to introduce their cities and provinces. Some trainees participated in activities of the local community and charity. One ex-trainee suggested that interacting with the local community had multi-faceted benefits and commented: "More people in the host countries know about China and it counteracts the biased information from local media. As a consequence, foreign friends and companies come and visit my city and new links have been established. The friendship flowers have born fruits”.

Apart from the positive impacts identified above some negative responses were 
collected from the interviews particularly with trainees, ex-trainees and supervisors. The negative views from ex-trainees and trainees are summarised as: that training is not beneficial to management reality, that it is difficult to use their learning, and that promotion is unsatisfactory. Criticisms are also heard from ex-trainees' supervisors, for example, that there is no significant positive change in the subordinates, and ex-trainees are too idealistic and dogmatic in copying the 'Western way', which could sometimes lead to disagreements with other colleagues. One supervisor commented that his subordinate did bring new concepts and became more ambitious. But some ideas were not realistic to apply to their business reality. "We believe in harmony of the working environment. So I have to balance between the traditional management style which has been accepted and innovation brought in by the manager (ex-trainee) based on Western management theory”, said one supervisor.

\section{Discussions and Implications}

Attributes of the Major Stakeholders Involved in China's Overseas Management Training and Development

As discussed earlier five major stakeholders are involved in the process of China's overseas management training and development. These stakeholders are categorised according to cultural dimensions.

As shown in Figure 1 four stakeholders are categorised in one culture, Chinese culture; whereas the training institution is categorised in this case in an Anglo-Saxon cultural region. However, the configuration of relationship varies in different phases of training intervention. Trainees and ex-trainees are 'mobile agents' who encounter other stakeholders and who experience both cultures at different times. Chinese managers are therefore challenged by the change of management concept and practices underpinned by distant cultural dimensions (Brown, 2002, Noe, 1986; Abdalla and Al-Homoud, 1995;Bartram and Gibson, 1999; Antonacopoulou, 1999). This leads to the individual development. It also accounts for the differences in responses between Chinese managers and Western training institution as well as between Chinese managers and their organisations such as supervisors and peers. 
Figure 1 Positioning of Stakeholders by Cultural Identity

\section{Home country: Chinese culture}

Host country: Anglo-Saxon culture

(a) Before training

Training organisers

Training departments

Chinese managers

Trainees' supervisors

(b) In training

Training organisers

Training department

Trainees’ supervisors

(c) After training

Training organisers

Training departments

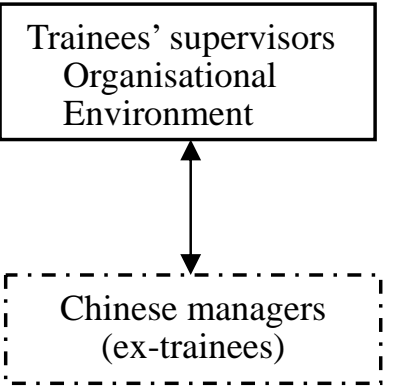

Training Institutions

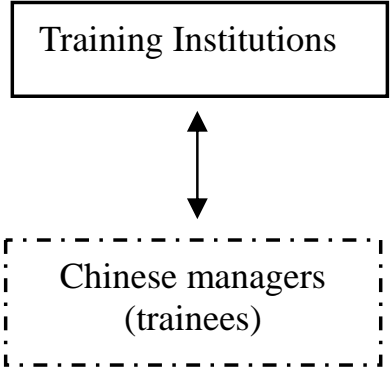

Training Institutions

Another possible reason for differing responses may be related to stakeholders' different roles in the training process. From a business point of view the training organiser is a direct client of a training institution. Chinese managers are not usually acknowledged in the contract in relation to training delivery such as objectives, contents of training and facilities prior to the training. In addition, a smooth and accurate flow of information is not always guaranteed between the economic buyer, a training organiser and the programme deliverer, a training institution; between training department/organiser and trainees and their supervisors; and between training deliverer and trainees. This therefore causes confusion in the training process, for example conflicts between learners and teachers in the learning process, which can be described as a conflict over 
meeting the expectations of Chinese managers. Moreover training institutions might not expect an information block at the China end.

Furthermore training departments and training organisers initiate the intervention, make relevant policies, and administrate the process. However this party can only work through other parties. From this perspective training departments and organisers act as a carrier for China's overseas management training and development. The diverse roles and imbalanced power and interests of the major stakeholders may therefore account for some key problems influencing training effectiveness. The typical example is that Chinese managers and their organisations have the least influence on the key issue in training such as subject matter, contents and methods of delivery in spite of their highest interests in the management training intervention.

\section{Conceptual and Perceptual Problems of China's Overseas Management Training}

The review of literature showed arguments in relation to definitions and notions of management training and development. The term China's overseas "management training” could mislead one into adopting a narrower concept in the light of the theories of previous work. Perhaps as a consequence of this information there is disagreement between stakeholders about the appropriateness of management development methods, and quality of delivery. For example the UK training institutions under investigation hold the most positive views about the total quality of training delivery and methods of delivery, particularly for 'instruction'. On the other hand complaints are heard from the interviewed Chinese managers that there is too much theoretical teaching, and not enough work practice in management reality. The key problem which needs to be addressed here is the difference between: (a) management education in an educational institution, (b) management training for development. The former activity focuses on management knowledge and skills in academic area, whereas the second one places more emphasis on management practices in the form of company visits, work experiences.

The confusion over the definitions of management training and development therefore appears to be a key reason for different perceptions between training institutions and other stakeholders regarding the approaches of training delivery. This study reveals that in reality the intervention of China's overseas management training contains a broader meaning. Firstly it is under the 'hat' of management development which aims to 
improve managerial work to embrace and deliver business changes through both planned and deliberate formal learning and informal experiential learning. The implication is that China's overseas management training focuses on the process of learning and development rather than one training intervention. Secondly, China's overseas management training is also characterised by reframing and developing managers' mindsets such as refining and influencing attitude, insights, concepts, and values. It mostly aims at changing the whole person and total career with a long-term pay-off and intangible benefits rather than short-term results. Thirdly, learning takes place for Chinese managers not only by formal and structured training delivery but also by participating other activities such as cultural visits, interacting with the locals, and daily life in host countries.

\section{Objectives' Problems of Training Delivery}

There is consensus in previous research that any management development activity should link closely to business strategies and focus on the managerial reality of an organisation. It is also argued that management training should address individual needs. The analysis of power and interests of stakeholders in China's management development intervention has revealed an imbalance of power and interests between Chinese policy-makers and Chinese managers and their organisations. In addition hardly any needs assessment in China's overseas management training intervention has been found either at organisational or individual levels. Indeed, meeting the 'designed objectives' drawn up by the initiators and organisers of Chinese management training is more satisfactory than meeting the organisational and individuals' objectives in this research. This raises questions of: (a) what the objectives written in the training protocols agreed by Chinese training organisers and UK training institutions are based on? (b) to what extent do they link with the organisational and individuals' objectives? This confusion over different objectives leads to various problems such as difficulties in identifying contents and methods of delivery, which in turn affects the effectiveness of learning and quality of training delivery.

Indeed the empirical study exposes the fact that training departments and organisers emphasise the factor of training objectives less than other stakeholders and that the respondents from training institutions have little awareness of what the training objectives are. This causes a mismatch between the delivery of training and the 
expectations of trainees. In addition the findings show that individual stakeholders have different focus on factors affecting learning. This shows that there is also lack of clarity over factors affecting learning effectiveness between the stakeholders. Therefore, in order to enhance the quality of China's overseas management training, issues need to be addressed in training needs assessment for management development, in setting up clear objectives, and in establishing smooth communications among the stakeholders involved.

Methodological problems for China's overseas management training and development Previous research suggests that the course design and pedagogical approach in cross-cultural teaching and learning needs to be culturally sensitive. Selvarajah's recent study (2006) reveals different educational objectives and attitudes to assessment methods between Chinese students and European students who take postgraduate management courses. According to some authors (Kolb et al., 2001; Yamazaki and Kayes, 2004; Kayes, 2005) individuals' learning preferences in a new culture determine their learning attributes such as skills, ability, styles and attitudes. It has therefore becomes a challenge for Western training institutions to design and deliver training courses for Chinese managers in a group setting without knowing their career backgrounds and individuals' needs before delivery.

Modern theory of management development suggests that it is hard to separate formal and structured training from informal management development activities (Mumford, 1997; Thomson et al., 2001; Mintzberg, 2004). The empirical results of Chinese management training in the UK support this argument. This raises the issue of availability of resources in the host country; whether there is a demand from the local organisations and communities; and to what extent the western training institutions are committed to bridging the needs between Chinese managers and the locals.

Last but not least, the findings of this research demonstrate that the effectiveness of Chinese managers learning is influenced by those factors beyond training delivery. It refers to wider range of activities occur in everyday life in host country. The awareness of the Western training providers to these factors is critical to ensure the learning efficiency of Chinese managers'. This therefore requires not only academic support but also non-academic facilitations to those students from other cultural backgrounds. 


\section{Conclusions}

In recent years, with the development of the institutional reform and WTO-regulation adaptation, there is an increasing demand for managerial expertise in public administration, business management, human resource management, finance, and social development. Although many local management training centres and educational institutions in China offer the management training and development courses (Alon and Lu, 2004; Cooke, 2005) the policy makers also choose to cooperate with the training institutions abroad, particularly in Western countries (Jiang, 2002; Sun, 2004). Compared with taking management training in China, studying abroad aims to expose Chinese managers to the 'real world' of modern management which originates from the West. It allows the managers to learn not only from textbooks but also from working with the organisations of host countries and other activities. Learning is therefore attained through structured management programmes as well as experiential and accidental learning.

China's overseas management training intervention has shown its unique characteristics for management development. The impacts are multi-faceted, which covers economic, social influences in the levels of individuals, organisations and regional. Some problems exist in terms of training delivery for management development. The major reason results from the complexity of stakeholders' attributes, and the diversity of training objectives. The cross-cultural context also influences the effectiveness of China's overseas management training and development. It is therefore a challenge for Chinese policy makers to take measures in clarifying the objectives of training programmes, meeting the needs of organisations and individual, as well as establishing a system of management development with close cooperation with training providers abroad. 


\section{References:}

Abdalla, I. A. and Al-Homoud, M. (1995) 'A survey of management training and development practices in the State of Kuwait', Journal of Management Development, 14 (3), pp. 14-25.

Alon, I. and Lu, L. (2004) 'The state of marketing and business education in China', Marketing Education Review, 14 (1), pp. 1-10.

Antonacopoulou, E. P. (1999) 'Training does not imply learning: the individual's perspective', Internaitonal Journal of Training and Development, 3 (1), pp. 14-33.

Ashton, D. J. L. and Easterby-Smith, M. (1978) Management Development in the Organisation, (London: Macmillan).

Badger, B. and Sadler-Smith, E. (1997) 'Outdoor management development', Journal of European Industrial Training, 21 (8/9), pp. 318-25.

Barry, T. (1999) 'Vision and Values: Practical guidance for Training and Development Professionals', in Landale, A. (Ed) Gower Handbook of Training and Development, (Gower Publishing Limited).

Bartram, S. B. and Gibson, B. (1999) 'Identifying training needs', in Landale, A. (Ed) Gower Handbook of Training and Development, (Gower Publishing Limited).

Batonda, G. and Perry, C. (2003) 'Influence of culture on relationship development processes in overseas Chinese/Australian networking', European Journal of Marketing, 37 (11/12), pp. 1548-74.

Beardwell, I. and Holden, L. (2001) Human Resource Management (3 edn), (London: Sage Publications).

Bernhard, H. B. and Ingols, C. A. (1988) 'Six lessons for the corporate classroom', Harvard Business Review, September-October, pp. 40-7.

Berrell, M., Wrathall, J. and Wright, P. (2001) 'A model for Chinese management education: adapting the case study method to transfer management knowledge', Cross Cultural Management, 8 (1), pp. 28-44.

Bolt, J. F., Bures, A. L., Banks, M. C. and Bula, R. J. (1983) 'Are we meeting the management training challenge?' Training and Development Journal, 39 (1), pp. 60-7.

Borgonjon, J. and Vanhonacker, W. R. (1994) 'Management training and education in the People's Republic of China', The International Journal of Human Resource Management, 5 (2), pp. 327-55.

Bramley, P. (1996a) Evaluating Training, (London: Institute of Personnel and Development).

Bramley, P. (1996b) Evaluating Training Effectiveness (2nd edn), (London: McGraw-Hill).

Branine, M. (2005) 'Cross-cultural training of managers: An evaluation of a management development programme for Chinese managers', Journal of Advanced Development, 24 (5), pp. 459-72.

Brown, J. (2002) 'Training needs assessment: a must for developing an effective training program', Public Personnel Management, 31 (4), pp. 569-78.

Cambell, J. P., Dunnette, M. D., Lawler, E. E. I. and Weick, K. R. (1970) Managerial behavior, performance, and effectiveness, (New York: McGraw-Hill). 
Child, J. (1994) 'Management in China during the age of reform', (Cambridge: Cambridge University Press).

Child, J. and Rodrigues, S. (2005) 'The internationalisation of Chinese firms: a case for theoretical extension?' Management and Organisation Review, 1 (3), pp. 381-410.

Chow, K. W. (1991) 'Perform of the Chinese cadre system: pitfalls, issues and implications of the proposed civil service system', International Review of Administrative Science, 57, pp. 25-44.

Chu Ng, Y. and Siu, N. Y. M. (2004) 'Training and enterprise performance in transition: evidence from China', International Journal of Human Resource Management, 15 (4/5), pp. 878-94.

Cooke, F. L. (2003) 'Seven reforms in five decades: civil service reform and its human resource implications in China', Journal of Asia Pacific Economy, 8 (3), pp. 380-404.

Cooke, F. L. (2005) HRM, Work and Employment in China, (London and New York: Taylor \& Francis Group).

Deng, X. P. (1978a) 'Carry out the policy of opening to the outside world and learn advanced science and technology from other countries', in Deng, X. P. (Ed) Selected Works of Deng Xiaoping, (Beijing: Renming Publications).

Deng, X. P. (1978b) 'Update enterprise with advanced technology and managerial expertise', in Deng, X. P. (Ed) Selected Works of Deng Xiaoping, (Beijing: Renming Publications).

Deng, X. P. (1982) 'Opening speech at the Twelfth National Conference of the Communist Party', in Deng, X. P. (Ed) Selected Works of Deng Xiaoping, (Beijing:Renming Publications).

Development of Employment (1971) Glossary of Training Terms (2nd edn), (London: HMSO).

Easterby-Smith, M. (1994) Evaluating Management Development, Training and Education (2nd edn), (Aldershot, Hampshire: Gower Publishing Limited).

Frese, M., Beimel, S. and Schoenborn, S. (2003) 'Action training for charismatic leadership: two evaluations of studies of a commercial training module on inspirational communication of a vision', Personnel Psychology, 56, pp. 671-697.

Glover, L. and Siu, N. (2000) 'The human resource barriers to managing quality in China', International Journal of Human Resource Management, 11 (5), pp. 867-82.

Goodall, K., Warner, M. and Lang, V. (2004) 'HRD in the People's Republic: the MBA "with Chinese characteristics"?' Journal of World Business, 39 (4), pp. 311-23.

Griffiths, K. and Williams, R. (1999) 'Learning for Change', in Landale, A. (Ed) Gower Handbook of Training and Development, (Gower Publishing Limited).

Hamblin, A. C. (1974) Evaluation and Control of Training, (London: McGraw-Hill Book Company (UK) Limited).

Holden, L. (1991) 'European trends in training and development', International Journal of Human Resource Management, 2 (2), pp. 113-22.

Iles, P., Wang, C. and Yolles, M. I. (2004) 'Knowledge Migration, HRM and knowledge transfer from Western to Chinese organisations', In 2nd Workshop of European Institute for Advanced Studies in Management in International Strategies and Cross-cultural Management, (Edinburgh). 
Jiang, B. Q. (Ed) (2002) Regulations of overseas training, (Beijing: China Ren Shi Publication).

Jick, T. D. (1979) 'Mixing qualitative and quantitative methods: triangulation in action', Administrative Science Quarterly, 24, pp. 602-11.

Johnson, B. and Turner, L. A. (2003) 'Data Collection Strategies in Mixed Methods Research', in Tashakkori, A. and Teddlie, C. (Eds) Handbook of Mixed Methods in Social \& Behavioral Research, (Thousand Oaks, London, New Delhi: SAGE Publications).

Kayes, D. C. (2005) 'Internal validity and reliability of Kolb's learning style inventory versions 3 (1999)', Journal of Business and Psychology, 20 (2), pp. 249-57.

Kemper, E. A., Stringfield, S. and Teddlie, C. (2003) 'Mixed methods Sampling Strategies in Social Science Research', in Tashakkori, A. and Teddlie, C. (Eds) Handbook of Mixed Methods in Social \& Behavioral Research, (Thousand Oaks, London, New Delhi:SAGE Publications).

Kolb, D. A., Boyatizis, R. E. and Mainemelis, C. (2001) 'Experiential Learning Theory: Previous Research and New Directions', in Sternberg, R. J. and Zhang, L. F. (Eds) Perspectives on cognitive, learning, and thinking styles, (New Jersey:Lawrence Erlbaum Associates Inc).

LaHote, D., Simonetti, J. L. and Longenecker, C. O. (1999) 'Management training and development at Aeroquip-Vickers, Inc.: a process model part 1', Industrial and commercial Training, 31 (4), pp. 132-7.

Longenecker, C. O. and Laurence, S. F. (2005) 'Management training: benefits and lost', Industrial and commercial Training, 37 (1), pp. 25-30.

Mabey, C. (2002) 'Mapping management development practice', Journal of Management Studies, 39 (8), pp. 1139-60.

Mabey, C. and Thomson, A. (2000a) 'The determinants of management development: the views of MBA graduates', British Journal of Management, 11, pp.S3-S16.

Mabey, C. and Thomson, A. (2000b) 'Management development in the UK: a provider and participant perspective', International Journal of Training and Development, 4 (4), pp. 272-86.

Mayo, A. (1998) Creating a Training and Development Strategy, (Institute of Personnel and Development).

McCalman, J. and Paton, R. A. (1992) Change Management, (London: Paul Chapman Publishing Ltd).

Mendenhall, M. E., Black, J. S., Jensen, R. J. and Gregersen, H. B. (2003) 'Human resource management challenges in the age of globalization', Organizational Dynamics, 32 (3), pp. 261-74.

Mintzberg, H. (2004) 'Third-generation management development', Training and Development, 58 (3), pp. 28-38.

Mintzberg, H. and Gosling, J. (2002) 'Educating managers beyond borders', Academy of Management Learning and Education, 1 (1), pp. 64-76.

Mullins, L. J. (2002) Management and Organizational Behaviour (6th edn), (Financial Times, Prentice Hall).

Mumford, A. (1989) Management Development: Strategies for Action, (Institute of Personnel Management). 
Mumford, A. (1997) Management Development Strategic for Action (3rd edn), (Devon: Institute of Personnel and Development).

Nadler, L. (1984) The Handbook of Human Resource Development, (New York: Wiley-Interscience).

Newell, S. (1999) 'The transfer of management knowledge to China: building learning communities rather than translating Western textbooks?' Education and Training, 41 (6/7), pp. 289-93.

Noe, R. A. (1986) 'Trainees' attributes and attitudes: neglected influences on training effectiveness', Academy of Management Review, 11 (4), pp. 736-49.

Pilbeam, S. and Corbridge, M. (2002) People Resourcing (2nd edn), (Prentice Hall).

Rothwell, W. J. and Kazanas, H. C. (1994) Human Resource Development A Strategic Approach (2nd edn), (Amherst, Massachusetts: HRD Press Inc).

Sels, L. (2002) 'More is not necessarily better': the relationship between the quantity and quality of training efforts', International Journal of Human Resource Management, 13 (8): 1279-98.

Selvarajah, C. (2006) 'Cross-cultural study of Asian and European student perception', Cross Cultural Management, 13 (2), pp. 142-55.

Silverman, D. (2000) Doing Qualitative Research, (London: SAGE Publications).

Sun, H. Z. (Ed) (2004) Questions and answers of training abroad, (Beijing, China:China Renshi Publication).

Tashakkori, A. and Teddlie, C. (1998) Mixed Methodology, (London, Delhi: SAGE Publications).

Thomson, A., Mabey, C., Storey, J., Gray, C. and Iles, P. (2001) Changing Patterns of Management Development, (Blackwell Publishers Ltd).

Thornhill, A., Lewis, P., Millmore, M. and Saunders, M. (2000) Managing Change, (London: Financial Times, Prentice Hall).

Warner, M. (1993) 'Human resource management 'with Chinese characteristics", The International Journal of Human Resource Management, 4 (1), pp. 45-64.

Warner, M. (2004) 'Human resource management in China revisited: introduction', International Journal of Human Resource Management, 15 (4/5), pp. 617-34.

Yamazaki, Y. and Kayes, D. C. (2004) 'An experiential approach to cross-cultural learning: a review and integration of competencies for successful expatriate adaptation', Academy of Management Learning \& Education, 3 (4), pp. 362-79.

http://english.peopledaily.com.cn/, 'China Sends Administrative Officials to Study Abroad', People's Daily Online, 2001, accessed September 2004.

http://news.xinhuanet.com/newscenter/2002-06/11/content_435834.htm,'2002-2005 China

National Talent Construction Plan and Strategy’, Xinhuanet, 11 June 2002, accessed

October 2005. 